ISSN No 2086-7956 E-ISSN No 2615-5494

\title{
RESPONS PETANI TERHADAP TEKNOLOGI LARIKAN GOGO (LARGO) DI KABUPATEN BENGKULU TENGAH
}

\author{
Response of Farmers to LARGO Technology \\ in Central Bengkulu Regency
}

\begin{abstract}
Ahmad Damiri, Andi Ishak, Linda Harta, Shannora Yuliasari, Herlena Bidi Astuti dan Emlan Fauzi
\end{abstract}

Balai Pengkajian Teknologi Pertanian Bengkulu, Badan Litbang Kementan e-mail: ahmaddamiri.bptp.bengkulu@gmail.com

\begin{abstract}
ABSTRAK
Teknologi larikan gogo (LARGO) adalah salah satu teknologi yang dihasilkan Badan Litbang Pertanian untuk intensifikasi padi di lahan kering. Teknologi tersebut perlu didiseminasikan kepada petani pada daerah sentra produksi padi gogo. Penelitian ini bertujuan untuk mengetahui respons petani terhadap komponen teknologi LARGO. Penelitian dilaksanakan pada bulan November 2019 melalui survei terhadap 10 orang petani pada saat sosialisasi teknologi LARGO kepada petani dan penyuluh di Kabupaten Bengkulu Tengah. Data dikumpulkan dengan metode before-after untuk menilai respons terhadap 14 komponen teknologi LARGO sejak dari pengolahan tanah, penggunaan benih, pemupukan, pengendalian OPT, penggunaan ZPT, dan umur panen. Data dianalisis secara deskriptif menggunakan kelas interval dan statistik dengan Uji Wilcoxon. Hasil penelitian menunjukkan bahwa metode sosialisasi efektif meningkatkan respons petani terhadap seluruh komponen teknologi LARGO menjadi baik. Terdapat tujuh komponen teknologi LARGO yang meningkat secara signifikan yaitu: (1) perlakuan benih, (2) pemupukan II, (3) pemupukan III, (4) aplikasi fungisida pada 80 hst, (5) penggunaan ZPT pada 83 hst, (6) aplikasi insektisida pada 86 hst, dan (7) umur panen 119 hst
\end{abstract}

Kata kunci: LARGO, komponen teknologi, respons, petani.

\section{PENDAHULUAN}

Pemerintah terus berupaya untuk meningkatkan produktivitas lahan padi ladang karena tekanan konversi lahan menyebabkan semakin menghilangnya lahan-lahan pertanian sawah khususnya pada daerah sentra produksi di Pulau Jawa sebagai lumbung padi nasional. Kementan (2015) memperkirakan laju konversi lahan sawah irigasi di Indonesia mencapai 100 ribu hektar per tahun, sekitar $80 \%$ terjadi di Pulau Jawa untuk kebutuhan perumahan, pabrik, infrastruktur, dan aktivitas industri. Sementara kemampuan pemerintah mencetak sawah baru hanya 40 ribu hektar per tahun. Hal ini mengkhawatirkan karena padi sawah irigasi rata-rata menyumbang $94,40 \%$ 
produksi padi nasional dalam periode 1969-2014 (BPS 2015). Selebihnya disumbangkan dari sawah pasang surut, rawa, dan sawah tadah hujan.

Tekanan konversi lahan tersebut menyebabkan Kementerian Pertanian melakukan optimalisasi produksi padi termasuk melirik potensi lahan kering untuk produksi padi gogo yang cukup besar potensinya di Indonesia, terutama di Sumatera dan Kalimantan sebagai daerah sentra perkebunan. Padi gogo secara tradisional telah dibudidayakan oleh masyarakat lokal dengan sistem ladang berpindah untuk kebutuhan konsumsi keluarga. Pada saat ini, padi gogo ditanam secara monokultur atau tumpangsari dengan tanaman pangan atau tanaman perkebunan muda.

Luas panen padi ladang atau padi gogo di Provinsi Bengkulu pada tahun 2015 adalah 8.429 ha atau $6,5 \%$ dari total luas panen padi. Dalam periode 2012-2015, produktivitas padi gogo hanya kira-kira setengah dari padi sawah yaitu 2,33 ton/ha (BPS Provinsi Bengkulu, 2018), hal ini salah satunya disebabkan oleh penerapan teknologi budidaya padi gogo yang masih tradisional.

Potensi peningkatan produktivitas padi gogo cukup besar dengan penerapan teknologi. Salah satunya adalah dengan teknologi LARGO Super yang dapat menghasilkan produktivitas 8 ton/ha (Soim, 2018). Komponen teknologi LARGO Super adalah cara tanam menggunakan alat tanam benih langsung (atabela), menggunakan varietas unggul padi gogo, sistem tanam legowo, perlakuan benih dengan pupuk hayati, penggunaan biodekomposer, dan pestisida hayati yang tepat (BPTP Bengkulu, 2018).

BPTP Bengkulu pada tahun 2019 telah melakukan sosialisasi teknologi LARGO bagi petani/KTNA dan penyuluh di Kabupaten Bengkulu Tengah, namun bukan LARGO Super. Hal ini karena khawatir inovasi teknologi LARGO super tidak berkelanjutan yang disebabkan oleh kesulitan bagi petani untuk mendapatkan bahan komponen teknologi seperti biodekomposer, bio prorector (pestisida hayati), dan pupuk hayati. Kesulitan ini disebabkan oleh kurangnya ketersediaan di pasar setempat terkait kebutuhannya relatif tidak banyak akibat luas tanam yang relatif sedikit dan tidak berkelanjutan bila dibandingkan dengan lahah sawah. Pengkajian ini bertujuan untuk mengetahui respons petani terhadap 
komponen teknologi LARGO yang dilakukan dengan memperkenalkan teknologi ini kepada para petani dan penyuluh lapangan.

\section{METODE PENELITIAN}

Penelitian ini dilakukan di Kabupaten Bengkulu Tengah pada bulan November 2019. Pengambilan data melalui survei dengan melibatkan 10 orang petani peserta sosialisasi teknologi dari 10 BPP Kabupaten
Bengkulu Utara. Pengambilan data dilakukan sebelum dan sesudah sosialisasi untuk mengetahui dinamika respons petani dan penyuluh terhadap komponen teknologi LARGO. Jumlah responden petani sebanyak 10 orang. Data yang dikumpulkan adalah komponen teknologi LARGO yang ditampilkan pada Tabel 1 menggunakan skala Likert dari sangat setuju (skor 5), setuju (skor 4), kurang setuju (skor 3), tidak setuju (skor 2), dan sangat tidak setuju (skor 1).

Tabel 1. Komponen teknologi LARGO untuk budidaya padi gogo.

Komponen teknologi

1. Pengolahan tanah dengan herbisida dan mesin potong rumput

2. Jumlah benih $50 \mathrm{~kg} / \mathrm{ha}$

3. Perlakuan benih dengan pestisida $10 \mathrm{gr} / \mathrm{kg}$ benih

4. Jumlah benih 5 biji/lubang tanam

5. Aplikasi herbisida pada umur $8-15 \mathrm{hst}$

6. Dosis pupuk NPK Phonska $200 \mathrm{~kg}+$ Urea $150 \mathrm{~kg} / \mathrm{ha}$

7. Pemupukan pertama (1/3 dosis) Pada $8-15$ hst yang dicampur dengan insektisida Furadan 3G sebanyak 16/ha

8. Aplikasi insektisida jika ada serangan pada umur 30 hst dan pada 32 hst dilakukan Penyemprotan fungisida

9. Pemupukan kedua (1/3 dosis) pada umur $40 \mathrm{hst}$

10. Pemupukan ketiga ( $1 / 3$ dosis) pada umur 60 hst dan lakukan pengendalian dengan fungisida dan jika ada serangan insek dilakukan penyemprotan dengan insektisida

11. Aplikasi fungisida pada serangan pada umur $80 \mathrm{hst}$

12. Aplikasi ZPT pada umur $83 \mathrm{hst}$

13. Aplikasi insektisida pada umur 86 hst

14. Panen pada $119 \mathrm{hst}$

Data dianalisis secara deskriptif dengan memetakan respons petani ke dalam dua kelas interval dan statistik menggunakan uji Wilcoxon. Rentang nilai interval kelas ditentukan dengan rumus (Sugiyono, 2009) : $\mathrm{P}=\mathrm{R} / \mathrm{K}$, dimana $\mathrm{P}=$ panjang kelas interval, $\mathrm{R}=$ skor tertinggi - skor terendah, dan $\mathrm{K}=$ jumlah kelas interval. Dari rumus tersebut diperoleh kelas interval sebagai 
berikut: (1) kelas interval I (kurang baik) dengan distribusi skor jawaban responden $1,0<\mathrm{X} \leq 3,0 ;$ (2) kelas interval II (baik) dengan distribusi skor jawaban $3,0<X \leq 5,0 . \quad$ Sementara itu, Uji Wilcoxon digunakan untuk menganalisis dua sampel berpasangan yang dianggap tidak terdistribusi normal apakah berasal dari populasi yang sama ataukah tidak (Santoso, 2012). Analisis data dilakukan dengan menggunakan program SPSS-16. Pengujian hipotesis Uji Wilcoxon dilakukan secara dua arah pada taraf keyakinan $95 \%(\alpha=0,05)$, dengan hipotesis sebagai berikut,

H0 diterima jika : nilai -Ztabel $\leq$ Zhitung $\leq$ Ztabel, yang berarti bahwa sosialisasi teknologi tidak mengubah respons petani dan penyuluh terhadap komponen teknologi LARGO;

H1 diterima jika : nilai Zhitung < Ztabel atau Zhitung $>$ Ztabel, yang berarti bahwa sosialisasi teknologi mengubah respons petani terhadap komponen teknologi LARGO;

Nilai Zhitung $\quad: \quad \pm 1,96$.

\section{HASIL DAN PEMBAHASAN}

\section{Kondisi Umum Lokasi Penelitian}

Sektor pertanian, kehutanan dan perikanan berperan penting dalam perekonomian Kabupaten Bengkulu Tengah karena merupakan sektor utama yang memberikan peranan terbesar dalam pembentukan Produk Domestik Regional Bruto (PDRB). Pada tahun 2018 peranan sektor pertanian, kehutanan dan perikanan terhadap PDRB Kabupaten Bengkulu Tengah adalah 29,18\% (BPS Kabupaten Benngkulu Tengah, 2019).

Luas panen padi sawah dan padi ladang di Kabupaten Bengkulu Tengah pada tahun 2015 adalah 7.634 ha dan $19,19 \%$ di antaranya merupakan luas panen padi ladang (BPS Provinsi Bengkulu, 2018). Masyarakat di Kabupaten Bengkulu Tengah umumnya menanam padi gogo satu kali setahun dengan cara tugal setelah olah tanah minimum atau tanpa olah tanah pada lahan-lahan bukaan baru di sela-sela tanaman perkebunan kelapa sawit. Setelah hutan ditebang, lahan dibersihkan dengan cara dibakar. Benih yang digunakan adalah benih lokal yang ditanam pada awal musim penghujan dan panen pada umur 6 bulan setelah tanam. Penanaman padi gogo 
berlangsung selama 2-3 tahun, sebelum tutupan kanopi tanaman kelapa sawit sudah tidak memungkinkan lagi untuk menanam padi gogo.

\section{Kabupaten Bengkulu Tengah} terdiri atas 11 kecamatan yang dibagi ke dalam 10 Balai Penyuluhan Pertanian (BPP). Berdasarkan hasil survei kepada penyuluh, kebutuhan teknologi budidaya padi secara umum masih dibutuhkan oleh seluruh BPP dibandingkan dengan komoditas lainnya.

Terdapat 5 dari 10 BPP yang masih membutuhkan teknologi padi gogo yaitu VUB Inpago 8, alat dan mesin pertanian (kultivator, caplak, power thresher), pemupukan, sistem tanam legowo, dan pengendalian OPT.

Kelima BPP tersebut yaitu: (1) BPP Merigi Kelindang Kecamatan Merigi Kelindang, (2) BPP Merigi Sakti Kecamatan Merigi Sakti, (3) BPP Pematang Tiga Kecamatan Pematang Tiga, (4) BPP Pagar Jati Kecamatan Pagar Jati, dan (5) BPP Bang Haji Kecamatan Bang Haji.

\section{Respons Petani terhadap Komponen Teknologi LARGO}

Respons petani terhadap komponen teknologi LARGO sebelum dan setelah sosialisasi mengalami peningkatan pada 14 komponen teknologi yang disosialisasikan (Gambar 1).

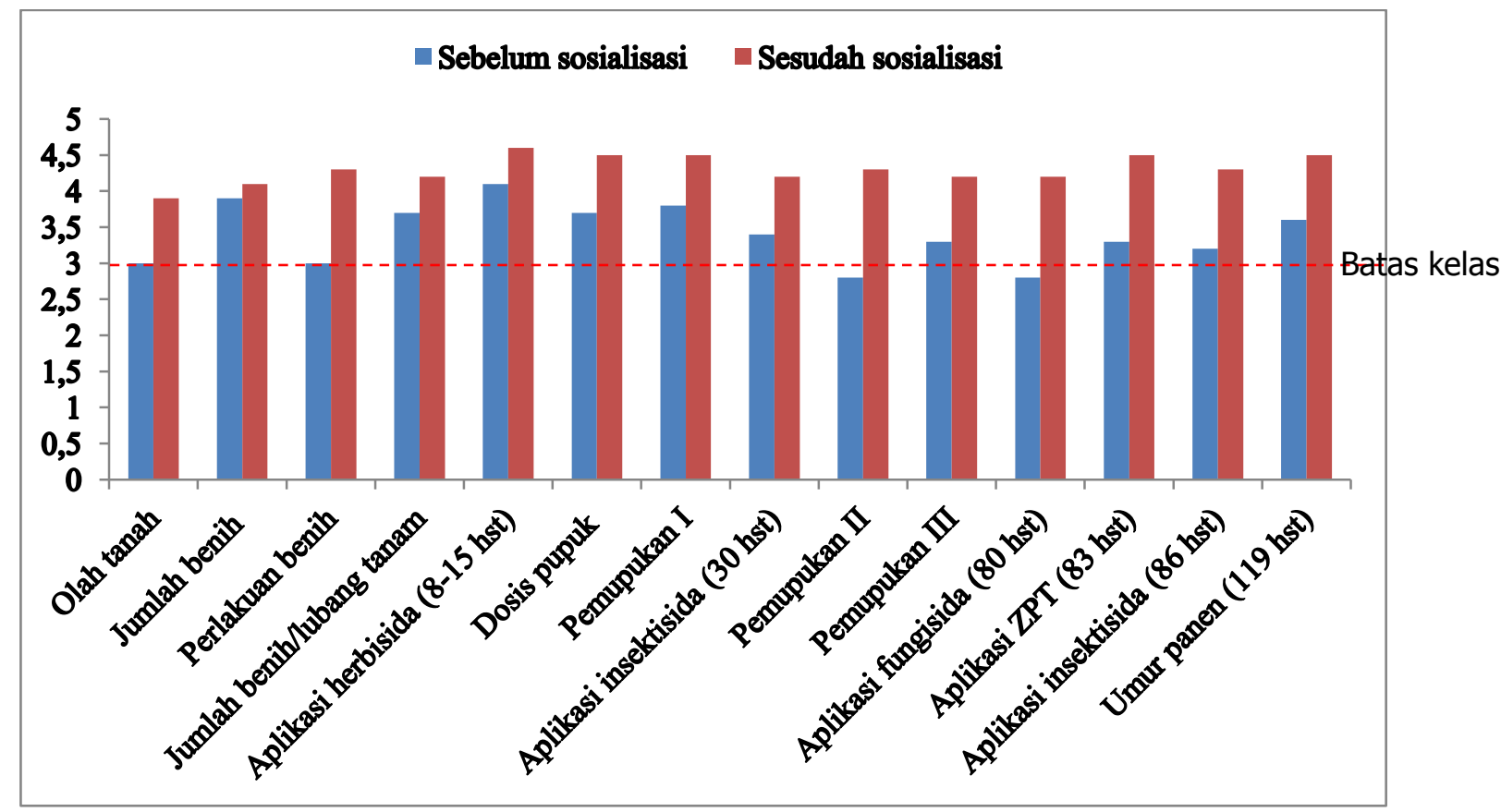

Gambar 1. Skor rata-rata respons petani terhadap komponen teknologi LARGO sebelum dan sesudah sosialisasi. 
Gambar 1 menunjukkan bahwa terdapat 4 komponen teknologi yaitu olah tanah, perlakuan benih, pemupukan II, dan aplikasi fungisida pada umur 80 hst memiliki skor pada kelas interval I $(1,0<X \leq 3,0)$ atau memiliki respons yang kurang baik sebelum sosialisasi dilaksanakan. Setelah pelaksanaan sosialisasi, respons petani seluruhnya menjadi baik atau berada pada kelas interval II $(3,0<X \leq 5,0)$. Hal ini menunjukkan bahwa metode sosialisasi efektif meningkatkan respons petani terhadap komponen teknologi LARGO.

Hasil analisis statistik pada Tabel 2 menunjukkan bahwa respons 10 orang responden meningkat secara nyata pada 7 komponen teknologi setelah sosialisasi yaitu: (1) perlakuan benih, (2) pemupukan II, (3) pemupukan III, (4) aplikasi fungisida pada 80 hst, (5) penggunaan ZPT pada 83 hst, (6) aplikasi insektisida pada 86 hst, dan (7) umur panen 119 hst.

Tabel 2. Hasil analisis respons petani terhadap teknologi LARGO Super dengan Uji Wilcoxon sebelum dan setelah sosialisasi.

\begin{tabular}{clccc}
\hline No & \multicolumn{1}{c}{$\begin{array}{c}\text { Perbandingan sebelum dan } \\
\text { sesudah }\end{array}$} & Z hitung & $\begin{array}{c}\text { Asymp. Sig. (2- } \\
\text { sisi)* }\end{array}$ & Keterangan \\
\hline 1 & Olah tanah & $-1,438$ & 0,150 & Ns \\
\hline 2 & Jumlah benih per hektar & $-0,333$ & 0,739 & Ns \\
\hline 3 & Perlakuan benih & $-2,214$ & $0,027^{*}$ & Sig \\
\hline 4 & Jumlah benih per lubang tanam & $-0,850$ & 0,396 & Ns \\
\hline 5 & Aplikasi herbisida (8-15 hst) & $-0,962$ & 0,336 & Ns \\
\hline 6 & Dosis pupuk per hektar & $-1,190$ & 0,234 & Ns \\
\hline 7 & Pemupukan I (8-15 hst) & $-1,725$ & 0,084 & Ns \\
\hline 8 & Aplikasi insektisida (30 hst) & $-1,299$ & 0,194 & Ns \\
\hline 9 & Pemupukan II (40 hst) & $-2,549$ & $0,011^{*}$ & Sig \\
\hline 10 & Pemupukan III (60 hst) & $-1,983$ & $0,047^{*}$ & Sig \\
\hline 11 & Aplikasi fungisida (80 hst) & $-2,913$ & $0,004^{*}$ & Sig \\
\hline 12 & Penggunaan ZPT (83 hst) & $-2,414$ & $0,016^{*}$ & Sig \\
\hline 13 & Aplikasi insektisida (86 hst) & $-2,414$ & $0,016^{*}$ & Sig \\
\hline 14 & Umur panen (119 hst) & $-2,460$ & $0,014^{*}$ & Sig \\
\hline
\end{tabular}

Keterangan: $*=$ Sig (berbeda nyata); Ns = (tidak berbeda nyata);

$$
\mathrm{Z}_{\text {tabel }} \alpha 0,05=1,96
$$

Perbedaan penentuan umur pada tanaman padi yang tanam pindah (padi sawah) dengan tanam tugal (padi gogo) berkisar antara 15 sampai 20 hari atau lebih. Umur tanaman padi sawah dihitung setelah penanaman dilakukan dari bibit berumur $15-20$ hari dan 
ISSN No 2086-7956 E-ISSN No 2615-5494

proses penanamannya yang juga membutuhkan waktu. Sedangkan umur tanaman padi gogo dihitung sejak penugalan benih dilakukan. Oleh karena itu kesamaan tahapan pertumbuhan tanaman antara padi sawah dan padi gogo lebih kurang 15 - 20 hari.

Pemeliharaan padi sawah relatif sama dengan pemeliharaan padi gogo. Oleh karena selisih perhitungan umur padi sawah dengan padi gogo berkisar antara 15 - 20 hari atau lebih, maka waktu pelaksanaan kegiatan pemeliharaan tanaman padi gogo dikurang 15 - 20 hari atau lebih akan setara dengan pemeliharaan tanaman padi sawah pada saat itu. Hal ini karena pemeliharaan padi gogo mengikuti pemeliharaan padi sawah.

\section{Perlakuan Benih.}

Perlakuan benih pada padi gogo sama dengan perlakuan pada persemaian padi sawah. Untuk menghindari serangan hama dari dalam tanah, benih padi gogo sebelum tanam dilakukan pencampuran dengan insektisida sistemik, racun kontak dan lambung berbahan aktif karbosulfan dengan dosisi 10 gram per kilo gram benih padi.

Kebiasaan petani dalam melakukan penanaman padi gogo, setelah ditugal, benih langsung ditabur. Kondisi ini kadang-kadang menyebabkan tanaman padi tidak tumbuh. Oleh karena itu informasi perlakuan benih untuk mengendalikan serangan hama terutama yang berada di dalam tanah menyebabkan responnya meningkat secara signifikan.

Perlakuan benih (Seed treatment) adalah upaya awal pengendalian hama sebelum benih ditanam. Benih padi gogo dicampur dengan insektisida bersifat sistemik. Hama padi gogo setelah benih tumbuh adalah lalat bibit, anjing tanah, dan uret (larva coleoptera) yang menyerang tanaman baru tumbuh (Suriansyah. 2013). Selanjutnya ditambahkan oleh Balitbangtan (2007). Hama lundi (Phyllophaga helleri Brsk), Merupakan hama utama pada tanaman padi gogo yang menyerang tanaman padi dengan cara memakan akar tanaman sehinga tanaman padi tidak dapat menyerap makanan dan akan menyebabkan kematian tanaman.

\section{Pemupukan II (40 hst) dan Pemupukan III (60 hst)}

Petani padi gogo biasanya tidak melakukan pemukukan ke II atau ke III. Mereka hanya melakukan pemupukan 
satu kali dalam satu musim tanam. Hal ini karena petani belum mengetahui pentingnya pemupukan ke II dan ke III pada tanaman padi khususnya padi gogo. Setelah dilakukan sosialisasi, mereka menjadi paham pentingnya pemupukan ke II dan ke III. Pada umur 60 hst, dilakukan penyemprotan fungisida dan jika ada serangan insek, dilakukan penyemprotan insektisida

Pemupukan pada padi sawah dikenal tiga tahap pemupukan yaitu: pemupukan pertama adalah tahap pertumbuhan awal tanaman, pemupukan ke dua merupakan tahap anakan produktif, dan pemupukan ke tiga merupakan tahapan inisiasi bunga. Pemupukan pertama pada umur $7-14$ hst, pemupukan ke dua pada umur 21 28 hst, dan pemupukan ke tiga pada umur $35-40$ hst.

Pada padi gogo tahapan pemupukannya menjadi pemupukan pertama berkisar antara $8-15$ hst, pemupukan ke dua berkisar 40 hst, dan pemupukan ke tiga berkisar 60 hst. Waktu pemupukan padi gogo ini sesuai dengan pendapat Menurut Afrizal Malik. 2017, bahwa tahapan pemupukan tanaman padi gogo yaitu umur 14 hst, 42 hst, dan 55 hst. Pemupukan ke dua perlu dilakukan karena pada saat itu tanaman pada tahap pembentukan anakan aktif dan pemupukan ke tiga merupakan tahap inisiasi bunga. Pada kedua tahap tersebut tanaman sedang membutuhkan makanan untuk pertumbuhannya.

\section{Aplikasi fungisida (80 hst)}

Kebiasaan petani terhadap serangan penyakit, dilakukan pengendalian bila tanaman sudah terlihat adanya serangan. Kadang kala karena kurangnya waktu dan ketelitian dalam pengamatan, serangan yang terlihat setelah malai mulai terlihat berwarna putih yang berarti serangan penyakit blas sudah terjadi. Pengendalian seperti ini sudah terlambat. Warna putih yang telihat pada malai menunjukkan bahwa tangkai malai sudah terpotong.

Salah satu penyakit yang menyerang tanaman padi dan sangat merugikan petani adalah penyakit blas. Pada kondisi tanaman sudah keluar malai, apabila tanaman terserang penyakit blas maka tangkai malai akan putus dan proses pengisian biji akan terhenti, akibatnya biji menjadi hampa atau tidak penuh (bernas). Oleh karena itu sebelum terjadinya serangan penyakit, perlu dilakukan pengendalian 
dengan penyemprotan fungisida yang bersifat sistemik dan kontak atau sitemik dan kontak yang saling bergantian.

Menurut Yuliani dan Yeni (2014), Untuk mengendalikan penyakit blas leher, dianjurkan menggunakan fungisida sistemik pada awal berbunga. Penggunaan fungisida pada saat yang tepat mampu menghambat serangan penyakit blas leher $60-80 \%$.

\section{Penggunaan ZPT (83 hst)}

Penyemprotan ZPT untuk meningkatkan kebernasan benih pada padi gogo sangat jarang di lakukan atau tidak dilakukan petani, karena kebanyakan padi gogo bukan merupakan tanaman utama tetapi hanya tanaman sampingan sebelum tanaman utama biasanya tanaman tahunan menghasilkan.

Pada tanaman padi sawah, rekomendasi aplikasi ZPT yaitu sebanyak 2 kali pada umur 45 dan 65 Hari Setelah Tanam (HST). Aplikasi pada umur 65 HST berfungsi untuk memaksimalkan proses pengisian gabah, sehingga bobot bulir gabah menjadi lebih tinggi, padat dan berisi bila dibandingkan dengan tidak semprot dengan ZPT. Pada padi gogo penyemprotan dilakukan pada sekitar umur 80 hst.

Penyemprotan ZPT berpengaruh nyata terhadap panjang malai dan jumlah gabah per malai. Hal ini sesuai dengan hasil penelitian (Utama dan Sugiyanta, 2016) yang dengan penyemprotan ZPT (giberelin) pada padi sawah dengan dosis yang berbedabeda menunjukkan panjang malai dan jumlah gabah permalai yang lebih tinggi dibandingkan dengan tanpa pemberian ZPT.

\section{Aplikasi insektisida (86 hst)}

Sama halnya dengan serangan penyakit, pengendalian serangan hama dilakukan apabila sudah terlihat adanya serangan. Apabila terlambat mengetahui adanya hama pada pertanaman padi, berarti serangan sudah terjadi beberapa waktu yang lalu. Pengendalian pada waktu itu mungkin akan berhasil mengendalikan serangan hama, tetapi serangan yang terjadi sebelumnya sudah menyebabkan kerugian hasil yang akan diperoleh.

Pada umur 86 hst dilakukan penyemprotan insektisida guna mengantisipasi serangan serangga yang menyerang pada fase generatif. Biasanya terdapat serangga Walang Sangit yang menyerang pada padi fase 
masak susu, serta serangga lainnya.

Walang sangit adalah serangga bertipe mulut pencucuk dan penghisap. Hama ini menghisap cairan biji padi yang menyerang sejak dari tanaman berbunga hingga masak susu (Kartohardjono dkk, 2009). Hasil Penelitian yang dilakukan Anggraini dkk (2014) pada padi sawah lebak di Sumatera Selatan, Serangan walang sangit mulai muncul pada tanaman padi umur 60 hst.

\section{Umur panen (119 hst)}

Kebiasaan petani menentukan umur panen berdasarkan kondisi kemasakan gabah di pertanaman, apabila tanaman padi umur panennya relatif cepat, petani sedikit terkejut karena tidak menyangka tanaman sudah akan panen. Hal ini karena umur panen dari setiap varietas dapat berbeda-beda.

Salah satu cara menentukan saat panen padi ditentukan oleh umur tanaman berdasarkan deskripsinya, selain berdasarkan 95\% gabah telah menguning. Padi gogo Inpago 8 akan panen setelah berumur 119 hari setelah tanam. Hal ini sesuai dengan deskripsi padi Inpago 8 pada deskripsinya (Balitbangtan, 2017)

\section{KESIMPULAN DAN SARAN}

Setelah dilakukan sosialisasi, respon petani menjadi lebih baik dibandingkan sebelum sosialisasi dan terdapat tujuh komponen teknologi yang meningkat secara signifikan yaitu: (1) perlakuan benih, (2) pemupukan II, (3) pemupukan III, (4) aplikasi fungisida pada 80 hst, (5) penggunaan ZPT pada 83 hst, (6) aplikasi insektisida pada 86 hst, dan (7) umur panen 119 hst. Rekomendasi paket teknologi LARGO disetujui oleh petani.

\section{UCAPAN TERIMA KASIH}

Terimakasih penulis sampaikan kepada teman-teman yang telah membantu selama penelitian. Ucapan terimakasih juga kepada bapak Dr. Yudi Sastro, SP, MP (Kepala BPTP Bengkulu) yang telah membantu memberikan saran dan masukan dalam pelaksanaan kegiatan penelitian.

\section{DAFTAR PUSTAKA}

Anggraini, S., Siti Herlinda, Chandra Irsan, dan Abu Umayah. 2014. Serangan Hama Wereng dan Kepik pada Tanaman Padi di Sawah Lebak Sumatera Selatan. Prosiding Seminar Nasional Lahan Suboptimal 2014, Palembang 26-27 September 2014 ISBN : 979-587-529-9. http://pur- 
plso.unsri.ac.id/userfiles/1_septia na-anggraini_red1(3).pdf[05 Mei 2020].

Balitbangtan. 2017. Deskripsi Varietas Unggul Baru Padi. Inbrida Padi Sawah Irigasi (INPARI), Hibrida Padi (HIPA), Inbrida Padi Gogo (INPAGO), Inbrida Padi Rawa (INPARA). Disusun Oleh: Ismail Wahab, Satoto, Ridwan Rachmat, Agus Guswara, dan Suharna. 2017.Badan Penelitian dan Pengembangan Pertanian. Kementerian Pertanian. .. 2007. Petunjuk Teknis Hama Penyakit. Pusat Penelitian dan Pengembangan Tanaman Pangan.

http://bbpadi.litbang.pertanian.go. id/index.php/publikasi/panduanteknis/petunjuk-teknis-hama-danpenyakit[04 Mei 2020].

BPTP Bengkulu, 2018. Teknologi Budidaya Padi Larikan Gogo Super (LARGO Super) dan Tumpangsari Tanaman (TURIMAN). Makalah disampaikan pada Temu Lapang Display UPSUS di Kabupaten Bengkulu Tengah pada tanggal 12 Desember 2018. Balai Pengkajian Teknologi Pertanian Bengkulu. Bengkulu. Tidak dipublikasikan.

BPS Kabupaten Bengkulu Tengah. 2019. Kabupaten Bengkulu Tengah Dalam Angka 2019. Badan Pusat Statistik Kabupaten Bengkulu Tengah. Kembang Seri.

BPS Provinsi Bengkulu. 2018. Provinsi Bengkulu Dalam Angka 2018. Badan Pusat Statistik Povinsi Bengkulu. Bengkulu.

BPS. 2015.Statistik 70 Tahun Indonesia
Merdeka. Badan Pusat Statistik. Jakarta.

Kartohardjono, A,. Denan Kertoseputro, dan Tatang Suryana. 2009. Hama Padi Potensial dan Pengendaliannya. Balai Besar Penelitian Tanaman Padi. http://www.litbang.pertanian.go.id /special/padi/bbpadi_2009_itp_16 .pdf[06 Mei 2020].

Kementan. 2015. Rencana Strategis Kementerian Pertanian Tahun 2015-2019. Kementerian Pertanian. Jakarta.

Santoso, S. 2012. Aplikasi SPSS pada Statistik Non Parametrik. PT. ElexMedia Komputindo. Jakarta.

Soim, A. 2018. Teknologi Largo Super Padi Gogo Dimasyarakatkan di Kabupaten Gorontalo. Sumber: https://tabloidsinartani.com/detail/ indeks/pangan/6833-teknologilargo-super-padi-gogodimasyarakatkan-di-kabupatengorontalo. Diunduh 28 April $\underline{2020}$.

Sugiyono. 2009. Metode Penelitian Pendidikan Pendekatan Kuantitatif, Kualitatif, dan RD. CV. Alfabeta. Bandung.

Suriansyah, Suparman, Andy Bhermana, dan Astrianto. 2013. Petunjuk Teknis Pengelolaan tanamanterpadu (PTT) Padi Gogo. Badan Penelitian dan Pengembangan Pertanian Balai Pengkajian Teknologi Pertanian Kalimantan Tengah. 
Utama, RC. dan Sugiyanta. 2016. Pengaruh Aplikasi Giberelin Pada Padi Sawah (Oryza Sativa L.) Varietas Hibrida (Hipa Jatim 2) dan Varietas Unggul Baru (Ciherang). Bul. Agrohorti 4(1): 56-62 (2016). file:///C:/Users/HP/Downloads/15 001-Article\%20Text-44378-1-1020170131.pdf[05 Mei 2020].

Yuliani, D dan Yeni Eliza Maryana. 2014. Integrasi Teknologi Pengendalian Penyakit Blas pada Tanaman Padi di Lahan SubOptimal. Prosiding Seminar Nasional Lahan Suboptimal 2014, Palembang 26-27 September 2014. ISBN: 979-587-529-9. http://pur-

plso.unsri.ac.id/userfiles/154\%20 DINI\%20YULIANI(2).pdf[04

Mei 2020]. 